\title{
$\begin{array}{ll}\text { Research Square } & \text { Preprints are preliminary reports that have not undergone peer review. } \\ \text { They should not be considered conclusive, used to inform clinical practice, }\end{array}$ or referenced by the media as validated information. \\ Challenges for National Deworming Policy in Indonesia: Experience From Bandung District West Java Province
}

\section{Riyadi Adrizain}

Universitas Padjajaran https://orcid.org/0000-0001-6939-3306

Djatnika Setiabudi

Universitas Padjajaran

Lia Faridah ( $\square$ lia.faridah@unpad.ac.id)

Universitas Padjajaran https://orcid.org/0000-0002-2387-1648

Nisa Fauziah

Universitas Padjadjaran

Budi Setiabudiawan

Universitas Padjadjaran

\section{Research Article}

Keywords: deworming, policy, Indonesia

Posted Date: May 6th, 2020

DOI: https://doi.org/10.21203/rs.3.rs-25514/v1

License: (c) (i) This work is licensed under a Creative Commons Attribution 4.0 International License. Read Full License 


\section{Abstract \\ Background}

The strategy of regular deworming has been the main STH control strategy recommended by the WHO for over a decade. In 2017, Indonesian government has also adapted this strategy by launching the Ministry of Health (MoH) Regulation No. 15 year 2017 regarding helminthiasis control. However, deworming effort is often hindered by various factors including poor hygiene, habits, and irregular mass drug administration in developing countries. To obtain a picture of how the deworming regulation is carried out and key challenges in Indonesia, this study investigated deworming conduct in Bandung District - one of the densest areas in Indonesia.

\section{Methods}

The main methodology was qualitative using published documents, interview and focus group discussion with related agencies such as $\mathrm{MoH}$, Bandung District Health Office, primary health care and cadres (community participants).

\section{Results}

From this study, we discovered incompleteness and inconsistency of conduct - even within a relatively small area such as Bandung District. Moreover, this study also found that deworming is combined with stunting programs in some areas without proper study directly correlating the improvement of nutritional status with reduced incidence of STH.

\section{Conclusions}

This study has demonstrated the challenges sustaining a consistent nationwide campaign over a wide area such as in Indonesia. In the end, we recommended that further nationwide evaluation is required placing emphasis on dissemination of policy to ensure more standardized conduct.

\section{Introduction}

The soil-transmitted helminthiasis (STH) is the most common neglected tropical disease worldwide. It is a type of helminth infection caused by various species of roundworm. Three major helminths underlying STH are Ascaris lumbricoides, Hookworm, and Trichuris trichiura which are prevalently found in endemic areas [1]. STH causes considerable health and economic burden - high to moderate STH infections are associated with increased risk of malnutrition, iron-deficiency anemia and other adverse physical and cognitive morbidities, particularly in children [2]. 
To tackle this problem, The World Health Organization (WHO) has set a global target to eradicate STHcaused morbidity by 2020 [3]. This can be achieved through conducting STH control by regular deworming in 75\% of preschool- and school-age children (aged 2-4 years and 5-12 years, respectively) in endemic areas. Subsequently, current WHO strategy for controlling STH relies on mass drug administration (MDA) of albendazole or mebendazole to pre-school and school-age children (PSAC and SAC), women of childbearing age (including pregnant women in the second-third trimesters and breastfeeding women) and adults in certain high-risk occupations such as agricultural laborers or miners $[2,4]$.

In recent decades, Southeast Asia has been recognized as a region with the highest prevalence of STH infection. Many countries in Southeast Asia have a moist climate that provides an ideal environment for STH embryonation, survival of eggs, and larvae maturation [5]. Amongst these countries is Indonesia there, STH infection is one of the main public health concerns with prevalence ranging from $45-65 \%$. In areas with poor sanitation, the prevalence can reach as high as $80 \%[6]$.

Aiming to mitigate STH prevalence in Indonesia, the government through the Ministry of Health (MoH) has launched the $\mathrm{MoH}$ Regulation No. 15 year 2017 regarding helminthiasis control. This regulation adopts the WHO recommendation for annual treatment in areas where the prevalence of STH is between $20 \%-50 \%$ and biannually where the prevalence is over $50 \%$ [5]. However, effective application of deworming regulation in developing countries is often hampered by lack of adequate water resources and poor sanitation infrastructure in many areas. Despite efforts to improve water resources availability and latrine utilization in these areas, complete eradication is also hindered by poor human sanitation habits and irregular mass drug administration [5, 7].

Now in 2020, we have reached the end year for the global target set by WHO [3]. It also has been three years since Indonesia has launched the newest deworming regulation. However, evaluation regarding the execution of this policy hasn't been carried out yet. In order to obtain a picture of how the deworming regulation is carried out in Indonesia, we studied the execution of the deworming policy in Bandung District, West Java. West Java is one of the densest areas in Indonesia, with a population of 46.497 .175 people - around 44\% among them living in Bandung City and Bandung District [8]. Through this study, we expect to identify key challenges in application of an effective deworming policy in Indonesia which could guide policymakers to design a more definitive control strategy for STH in the upcoming years.

\section{Methods}

\section{Ethical declaration}

This study was part of a main study, "The Relation of vitamin D, confounding and comorbid factor of stunting in an infant in Bandung District" which is approved by the Health Research Ethical Committee, Medical Faculty of Universitas Padjadjaran (No.1170/UN6.KEP/EC/2019).

\section{Study Area}


The study was conducted in Bandung District, West Java Province, Indonesia. This district covers an area of $1,762.39 \mathrm{~km}^{2}$ with a population of 4,069,872 people (density of 2,309.29 people/ $\mathrm{km}^{2}$ ). Bandung District is administratively divided into 31 sub districts and 270 villages. Most residents work in factories. Geographically, Bandung District lies between $6^{0} 41^{\prime}-7^{0} 19^{\prime} \mathrm{SL}$ and $107^{0} 22^{\prime}-108^{0} 5^{\prime} \mathrm{EL}$. The area is mountainous and is passed by the Citarum River. Because of poor drainage and sedimentation of the river, Bandung District is frequently flooded during the rainy season.

\section{Data collection and analysis}

This study employed qualitative approach, combining analysis of published documents, interview, and focus group discussion (FGD) involving related agencies such as $\mathrm{MoH}$, Bandung District Health Office, primary health care and cadres (community participants) to get information about how this deworming program conduct, the prevalence of STH in that area, MDA program for STH and what are the obstacles.

For the interview, we purposely selected several key informants $(n=15)$ amongst those agencies. Meanwhile, FGD was done involving primary health center workers and cadres $(n=80)$ across Bandung District. All of these were audiotaped and transcribed.

\section{Results}

Analysis of published documents: deworming as a national issue

The timeline of Indonesian deworming policy can be summarized in Figure 1. In 2009 to 2013, Indonesian nationwide program for deworming was conducted through an integrated MDA for filariasis - therefore, all data obtained then was measured in terms of filariasis incidence. Prior to commencement of the program, surveillance has shown that incidence of microfilaria was more than $1 \%$ across various municipalities and regencies in Indonesia. In order to reduce this incidence to less than 1\%, the MDA filariasis program in 2009-2013 was done by administering Diethylcarbamazine citrate (DEC) $6 \mathrm{mg} / \mathrm{kg}$ of body weight in combination with Albendazole $400 \mathrm{mg}$. Following a national report in 2017, this program has shown success in which 78 provinces in Indonesia demonstrated decrease to less than $1 \%$ microfilaria incidence (target $=55$ provinces) $[8,9]$.

Following the success of the 2009-2013 program, Indonesian government had set a new goal in deworming - reducing STH in Indonesia to $<10 \%$ in every district and city. To reach this goal, the government devised a new regulation which integrates deworming with MDA filariasis, school health care services, and vitamin A administration by using family 
health care approach (the $\mathrm{MoH}$ Regulation No. 15 year 2017 regarding helminthiasis control). Under this new regulation, intervention for STH is different for every area, depending on the prevalence of STH based on stool examination in the laboratory (Table 1) [9].

Table 1. Category of MDA of STH

\begin{tabular}{|c|c|c|c|}
\hline \multirow[b]{2}{*}{ Category } & \multirow[b]{2}{*}{ MDA } & \multicolumn{2}{|c|}{ Type of intervention } \\
\hline & & Area of MDA filariasis & Area non-MDA filariasis \\
\hline $\begin{array}{l}\text { Prevalence } \\
\geq 50 \%\end{array}$ & $\begin{array}{l}\text { Twice } \\
\text { a } \\
\text { year }\end{array}$ & $\begin{array}{l}\text { Children age } 1-12 \text { years old given } \\
1 \text { times/year, } 6 \text { months after MDA } \\
\text { filariasis }\end{array}$ & $\begin{array}{l}\text { Children age 1-12 years old given } \\
2 \text { times/year, } 6 \text { months after MDA } \\
\text { filariasis }\end{array}$ \\
\hline $\begin{array}{l}\text { Prevalence } \\
\geq 20 \% \quad \text { to } \\
<50 \%\end{array}$ & $\begin{array}{l}\text { Once } \\
\text { a } \\
\text { year }\end{array}$ & No additional MDA of STH & $\begin{array}{l}\text { Children age } 1-12 \text { years old given } \\
1 \text { times/year, } 6 \text { months after MDA } \\
\text { filariasis }\end{array}$ \\
\hline $\begin{array}{l}\text { Prevalence } \\
<20 \%\end{array}$ & - & - & Selective treatment \\
\hline
\end{tabular}

Under the condition where the laboratory resource is very limited or geographically challenging for stool examination, the area will be considered as having $>20 \%$ prevalence and the local MDA will be carried out for 4 to 6 years [9]. 
This new regulation also requires evaluation through prevalence study for roundworm, hookworm, and human whipworm for every five years of administration of MDA of STH. The study shall use a clustering survey method and the result of the study will decide the appropriate follow-up interventions in the surveyed area (Table 2) [9].

Table 2. Follow up post surveillance survey after MDA of STH

\begin{tabular}{|c|c|}
\hline Prevalence & Follow up \\
\hline$<1 \%$ & No additional treatment \\
\hline$\geq 1 \%-<10 \%$ & Once every 2 year \\
\hline$\geq 10 \%-<20 \%$ & Once annually \\
\hline$\geq 20 \%-<50 \%$ & Twice annually \\
\hline$\geq 50 \%$ & Three times annually \\
\hline
\end{tabular}

Furthermore, the regulation also mandates the local government to conduct the program. This includes supporting resources, mobilizing society to control the risk factor of $\mathrm{STH}$, administering MDA under supervision [9].

Real-life condition of deworming program in national level

Through interviews and FGD with health agencies in various levels of authority, the study obtained a visual summary of how the deworming program is carried out in Indonesia (Figure 2). 
In national level, an interview with the subdirectory of prevention and control of direct infection in the Ministry of Health Indonesia revealed that the deworming program is carried out differently in STH-endemic, stunting-prevalent, and other areas. In areas endemic to $\mathrm{STH}$, deworming is focused on administration of MDA annually for residents aging 2-70 years old. Meanwhile, in areas where cases of stunting are prevalent, MDA is only given to the younger population (1-12 years old) and pregnant women for twice a year. In other areas, deworming is done by annual supplementation of Fe tablets. On this level, the challenge in carrying out an effective program is the lack of compliance in society to take the MDA for STH.

Real-life condition of deworming program in Bandung District

Interview with the person-in-charge of the deworming program in the Bandung District Public Health Office revealed further about the implementation, surveillance study, and the follow-up interventions done in this area. In Bandung District, the deworming program has been conducted annually since 2009. The program focuses on the population aging 1-65 years old. For the first five year of the study (2009-2013), evaluation was carried out in September to October 2016, targeting the population of children in primary school grade 3 to 5 . The study involves 2 cluster targets and a total of 664 stool samples. These samples are collected through a sequence of directions: program holders educate teachers, who then teach their students. These students will relay the directions to their parents at home - the next morning, these students will bring the stool samples to school. These samples were then collected by officials and sent to the district laboratory. There, these samples were examined with Kato-Katz technique. The results showed prevalence of STH 1.95\%; with roundworm $1.2 \%$, human whipworm $0.85 \%$, while there is no hookworm found.

Following this result, the follow-up intervention for deworming should only conduct in children with positive STH. However, based on a letter from the Ministry of Health Indonesia number PV/04.02/Menkes/528/2017, the Bandung District should conduct MDA for STH twice a year in April and October in order to ensure reduction of STH infection to $10 \%$. In 
further development, a new policy regarding stunting in 2018 has altered the execution of the deworming program - deworming is only carried out in areas with a high number of stunting.

These changes of directions in the deworming program is reflected in information obtained from the person-in-charge of the deworming program in primary health care regarding what they know of the program. One of the noticeable findings in this level is the inconsistency of application of deworming programs. We also found that in several areas, further interventions after 2017 hasn't been done yet - presumably because of the success of the previous deworming program (2009-2013) and following change of policy to focus deworming only in areas with high stunting prevalence. The sample results of interview with person-in-charge in three different primary health care within Bandung District are given in Table 3.

Table 3. Sample results of interview with person-in-charge in primary health care 


\begin{tabular}{|c|c|c|c|}
\hline Question & $\begin{array}{c}\text { Person } 1 \\
\text { (Primary Health Care 1) }\end{array}$ & $\begin{array}{c}\text { Person } 2 \\
\text { (Primary Health Care 2) }\end{array}$ & $\begin{array}{c}\text { Person } 3 \\
\text { (Primary Health } \\
\text { Care 3) }\end{array}$ \\
\hline $\begin{array}{l}\text { When was the } \\
\text { last MDA for } \\
\text { STH conducted? }\end{array}$ & 2017 & 2017 & 2019 \\
\hline $\begin{array}{l}\text { How many times } \\
\text { a year? }\end{array}$ & Once a year & Once a year & Once a year \\
\hline $\begin{array}{l}\text { Why is the } \\
\text { program } \\
\text { conducted? }\end{array}$ & $\begin{array}{l}\text { Program is included in } \\
\text { filariasis, so it given } \\
\text { because of lymphatic } \\
\text { filariasis program }\end{array}$ & $\begin{array}{l}\text { Program is included in } \\
\text { filariasis, so it given } \\
\text { because of lymphatic } \\
\text { filariasis program }\end{array}$ & $\begin{array}{l}\text { Because the area } \\
\text { has lot } \\
\text { population of } \\
\text { stunted children }\end{array}$ \\
\hline $\begin{array}{l}\text { Is there any } \\
\text { other further } \\
\text { notice for } \\
\text { repeated } \\
\text { deworming? }\end{array}$ & Not yet & Not yet in 2018-2019 & $\begin{array}{l}\text { In area of } \\
\text { stunted children } \\
\text { will be } \\
\text { conducted twice } \\
\text { a year }\end{array}$ \\
\hline
\end{tabular}

\section{Discussion}

Sustaining a huge national campaign over a long period and wide area is a challenge in any society. Even though the prevalence of STH in Bandung District is very low, we found several aspects that could be 
improved. First, we identified an incomplete and inconsistent implementation of the program - as seen in the difference between information in national and regional levels of health agency (Fig. 1). This inconsistency is also found in surveillance of program status, as demonstrated in the case of Bandung District. There, evaluation of 2009-2013 program is conducted 2016 - three years after conclusion of the program. While indeed at that time, the MoH Regulation No. 15 year 2017 which dictates evaluation every five years hasn't been launched yet, evaluation of the deworming program should have been done immediately [10] in order to figure out the next step for the deworming program. Fortunately, the prevalence of STH infection in Bandung District is rather low in 2016 (1.95\%). However, significant decline in prevalence doesn't mean that the deworming program should stop immediately. Continuous monitoring should be done as part of disease control, as experience from Togo on STH program has demonstrated that abrupt stopping of MDA in areas with high baseline prevalence may result in significant rebound of infection [11-14]. Therefore, in the areas where prevalence of STH is high, repeated mass treatment for at least five consecutive years to prevent reinfection is needed [7].

Another area of improvement is the use of Kato-Katz technique in examining stool samples. Indeed, it has several advantages - it's inexpensive, widely used, and sensitive in detecting moderate or heavy infection (MHI) of STH. However, they have limitations regarding predictive values in low-prevalence settings and the effect of stool preparation (consistency, amount, part of stool sampled) to the result. The latter concern is also exacerbated due to the complex sequence of directions from program holders to students and its parents, increasing likelihood of obtaining inappropriate stool samples. In addition, some preliminary analysis from microscopy and PCR has suggested that hookworm infection may be misidentified [2].

The importance of STH to global child health is associated with their ability to cause chronic disability which often lasts throughout childhood and adolescence. Over this period, worms might stunt growth and cause intellectual and cognitive deficits [15]. This leads to the decision of the Ministry of Health Indonesia in 2018 to conduct a deworming program only in areas with a high number of stunting. Indeed, a previous study in several areas of Indonesia has demonstrated that deworming effectively improved the nutritional status in children. Before the deworming program, $33 \%$ of study participants were in good nutritional status, $47.7 \%$ of them were underweight, and $19.3 \%$ were severely underweight. After the deworming program, the percentage of participants with good nutritional status rose up to $75 \%$, while the percentage of underweight participants reduced to $25 \%$, and none of them were severely underweight $[7,16-17]$. However, there hasn't been any study which directly correlates the improvement of nutritional status with reduced incidence of STH. Through this study, we revealed that the deworming program in Bandung district has included areas with a high case of stunting. Nevertheless, further study to find the correlation between STH and stunting in Indonesia community would support the benefit of MDA for STH in the stunting population.

In this study, we highlighted the necessity of timely evaluation of the deworming program to determine its efficacy. We also suggest that consistency and implementation of this nationwide policy remains to be monitored and evaluated. 


\section{Conclusions}

There has been substantial progress in the deworming program in Indonesia with increasing coverage of MDA for STH although further actions to accelerate towards achieving the goal of $<10 \%$ in prevalence of STH in every city/district of Indonesia is still needed. Moreover, efforts to integrate STH deworming programs with stunting national programs also need further evaluation - especially in regards to dissemination of the policy to lower levels to ensure standardized conduct of the program.

\section{Abbreviations}

DEC

Diethylcarbamazine citrate

FGD

Focus group discussion

MDA

Mass drug administration

$\mathrm{MoH}$

Ministry of Health

PSAC

Pre-school age children

SAC

School-age children

STH

Soil-transmitted helminthiasis

\section{Declarations}

\section{Ethics approval}

This study was part of a main study, "The Relation of vitamin D, cofounding and comorbid factor of stunting in an infant in Bandung District" which is approved by the Health Research Ethical Committee, Medical Faculty of Universitas Padjadjaran (No.1170/UN6.KEP/EC/2019).

\section{Consent to participate}

Not applicable

\section{Consent for publication}

Not applicable. 


\section{Availability of data and materials}

Not applicable.

\section{Competing interests}

The authors declare no competing interests.

\section{Funding}

This study was funded by Universitas Padjajaran through Internal Research Grant scheme batch I, year 2019 (3855/UN6.C/LT/2019).

\section{Authors' contributions}

Funding acquisition: RA, LF, and BS. Data acquisition: RA and LF. Data curation: RA and LF. Formal analysis: RA and LF. Writing - original draft: RA and LF.

\section{Acknowledgements}

The author expresses their gratitude to field surveyors, staffs at the Primary Health Care centers, and the cadres at the Bandung district who has supported this study.

\section{Authors' information}

Department of Child's Health, Faculty of Medicine Universitas Padjadjaran/Dr.Hasan Sadikin General Hospitals in Bandung

Riyadi Adrizain, Djatnika Setiabudi, Budi Setiabudiawan

Parasitology Division, Department of Biomedical Science, Faculty of Medicine, Universitas Padjadjaran, Bandung, Indonesia 


\section{Corresponding author}

Lia Faridah

\section{References}

1. Clarke NE, Ng-Nguyen D, Traub RJ, Clements ACA, Halton K, Anderson RM, et al. A cluster-randomised controlled trial comparing school and community-based deworming for soil transmitted helminth control in school-age children: the CoDe-STH trial protocol. BMC Infect Dis. 2019;19:1-10.

2. Freeman MC, Akogun O Jr, Brooker VB, Gyorkos SJ, Imtiaz TW. R, et al. Challenges and opportunities for control and elimination of soil-transmitted helminth infection beyond 2020. PLoS Negl Trop Dis. 2019;13:1-10.

3. Becker SL, Liwanag HJ, Snyder JS, Akogun O, Belizario V Jr, Freeman MC, Gyorkos TW, Imtiaz R, Keiser J, Krolewiecki A, Levecke B, Mwandawiro C, Pullan RL, Addiss DG, Utzinger J. Toward the 2020 goal of soil-transmitted helminthiasis control and elimination. PLoS Negl Trop Dis. 2018;12:e0006606.

4. Lo NC, Snyder J, Addiss DG, Heft-Neal S, Andrews JR, Bendavid E. Deworming in pre-school age children: a global empirical analysis of health outcomes. PLoS Negl Trop Dis. 2018;12:1-13.

5. Pasaribu AP, Alam A, Sembiring K, Pasaribu S, Setiabudi D. Prevalence and risk factors of soiltransmitted helminthiasis among school children living in an agricultural area of North Sumatera, Indonesia. BMC Public Health. 2019;19:1-8.

6. Nasution RKA, Nasution BB, Lubis M, Lubis IND. Prevalence and Knowledge of Soil-Transmitted Helminth Infections in Mandailing Natal, North Sumatera, Indonesia. Open Access Maced J Med Sci. 2019;7:3443-6.

7. Sungkar S, Ridwan AS, Kusumowidagdo G. The effect of deworming using triple-dose albendazole on nutritional status of children in Perobatang Village, Southwest Sumba, Indonesia. J Parasitol Res. $2017 ; 2017: 1-5$.

8. Kementerian Kesehatan Republik Indonesia. Penyakit Tular Vektor dan Zoonosis. In: Profil Kesehatan Indonesia 2017. Kementerian Kesehatan Republik Indonesia. 2018.

https://www.kemkes.go.id/resources/download/pusdatin/profil-kesehatan-indonesia/ProfilKesehatan-Indonesia-tahun-2017.pdf. Accessed 23 April 2020.

9. Kementerian Kesehatan Republik Indonesia. Peraturan Menteri Kesehatan Republik Indonesia No. 15 tahun 2017 tentang penanggulangan cacingan. 2017. http://hukor.kemkes.go.id/uploads/produk_hukum/PMK_No._15_ttg_Penanggulangan_Cacingan_.pdf. Accessed 23 April 2020.

10. Mwandawiro CS, Nikolay B, Kihara JH, et al. Monitoring and evaluating the impact of national schoolbased deworming in Kenya: study design and baseline results. Parasites Vectors. 2013;6:198. 
11. Bronzan RN, Dorkenoo AM, Agbo YM, Halatoko W, Layibo Y, Adjeloh P, et al. Impact of communitybased integrated mass drug administration on schistosomiasis and soil-transmitted helminth prevalence in Togo. PLoS Negl Trop Dis. 2018;12:1-23.

12. Croke K, Atun R. The long run impact of early childhood deworming on numeracy and literacy: evidence from Uganda. PLoS Negl Trop Dis. 2019;13:1-20.

13. Ásbjörnsdóttir KH, Ajjampur SSR, Anderson RM, Bailey R, Gardiner L, Halliday KE, et al. Assessing the feasibility of interrupting the transmission of soil-transmitted helminths through mass drug administration: the deworm3 cluster randomized trial protocol. PLoS Negl Trop Dis. 2018;12:1-16.

14. Dunn JC, Bettis AA, Wyine NY, Lwin AMM, Tun A, Maung NS, et al. Soil-transmitted helminth reinfection four and six months after mass drug administration: results from the delta region of Myanmar. PLoS Negl Trop Dis. 2019;13:1-16.

15. Weatherhead JE, Hotez PJ. Worm Infections in Children. Pediatr Rev. 2019;36:341-54.

16. Clarke NE, Clements ACA, Doi SA, Wang D, Campbell SJ, Gray D, et al. Differential effect of mass deworming and targeted deworming for soil-transmitted helminth control in children: a systematic review and meta-analysis. Lancet. 2016;389:1-16.

17. Thayer WM, Clermont A, Walker N. Effects of deworming on child and maternal health: a literature review and meta-analysis. BMC Public Health. 2017;17:113-26.

\section{Figures}

\section{Timeline of Indonesian National Deworming Policy}

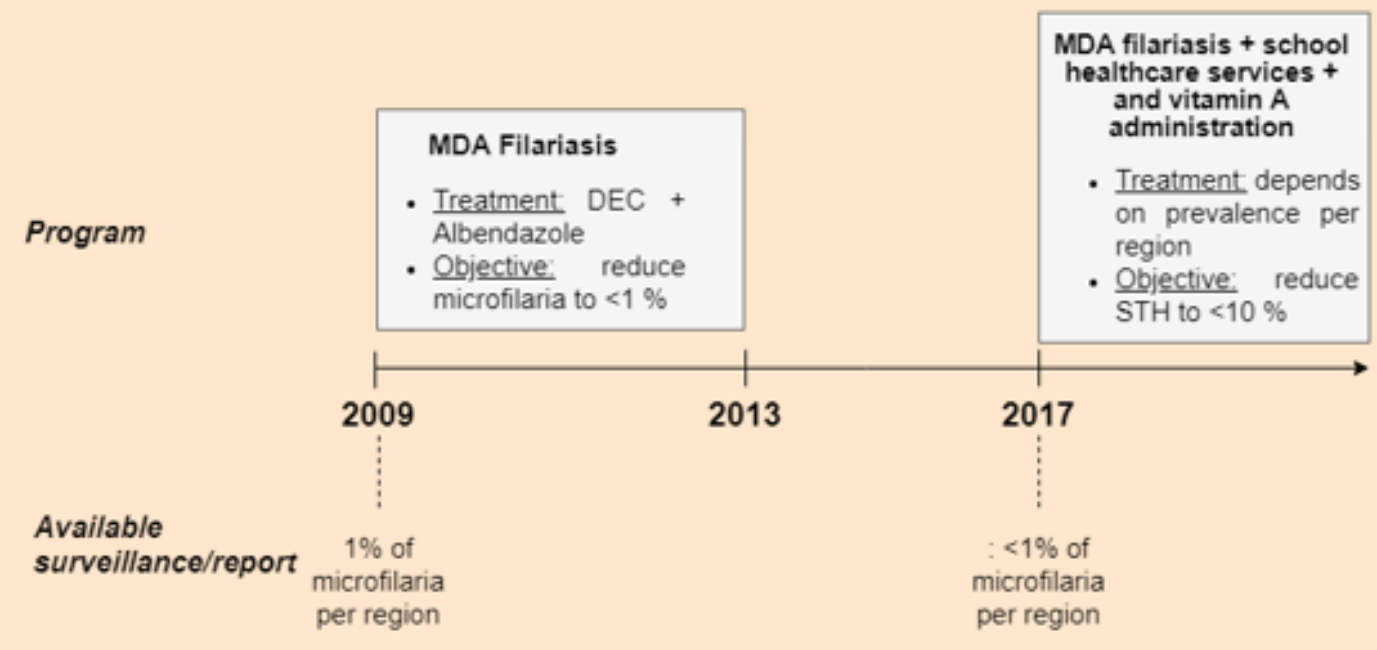

Figure 1 


\section{Execution of Deworming Program in Indonesia}

\section{National Level: the Ministry of Health Indonesia}

- In endemic areas, MDA is given annually for those aged 2-70 years old.

- In stunting areas, MDA is given for those aged 1-12 years old and pregnant women twice a year.

- In other areas, deworming is carried out annually with supplementation of Fe tablets.

- Lack of compliance in society.

\section{Regional Level: Bandung District}

- The deworming program has been conducted annually since 2009 . The program focuses on population ageing 1-65 years old.

- Last evaluation for the program was done in 2016 by stool sample examination employing Kato-Katz technique.

- The stool sample collection was done through a complicated relay of information: from program holders to teachers, from teachers to students, and from students to their parents.

- Through this study, they found a rather low prevalence of STH in Bandung District $(1.97 \%)$

\section{Local Level: Primary Health Care across Bandung District}

- In some areas, MDA was last carried out in 2017 as part of the lymphatic filariasis program.

- In other areas, MDA was last carried out in 2019 as part of the stunting program.

\section{Figure 2}

Visual summary of how the deworming program is carried out across different levels of authority within Indonesia. 